\title{
Prevalence of Various Reproductive Disorders in the Foothills of Himalaya
}

\author{
Chandra Prakash Dixit ${ }^{1 *}$, Dipak Bhuyan ${ }^{1}$, Manjyoti Bhuyan ${ }^{1}$, Kutubuddin Ahmed ${ }^{1}$, Sikhamoni Haloi ${ }^{2}$, \\ Dhrubajyoti Borpujari ${ }^{1}$, Himsikha Chakravarty ${ }^{1}$, Alapa Baba Ikpe ${ }^{1}$ and Mebanshan Nongkhlaw Lyngdoh ${ }^{1}$ \\ ${ }^{1}$ Department of Animal Reproduction, Gynaecology and Obsteterics, College of Veterinary Science, Assam Agricultural \\ University, Khanapara, Assam, INDIA \\ ${ }^{2}$ Department of Animal Nutrition, College of Veterinary Science, Assam Agricultural University, Khanapara, Assam, INDIA \\ *Corresponding author: C P Dixit; E- mail: winvinay.1990@gmail.com
}

Received: 07 July, 2020

Revised: 14 July, 2020

Accepted: 26 July, 2020

\begin{abstract}
The study was carried out to investigate the incidence of reproductive disorders in Assam region of India. A total of 554 crossbred cows were screened and survey was made to rule out prevalence of reproductive diseases. The risk factors such as age and parity were also taken into account to find the relation with occurrence of reproductive disorders. The anestrus (51.12\%), repeat breeding (RB; 33.71\%), retention of fetal membrane (RFM; 5.06\%), dystocia (4.50\%), abortion and cervicovaginal prolapse $(2.81 \%)$ were recognized as major reproductive disorder in Assam. Age had non-significant $(\mathrm{P}>0.05)$ effect in the prevalence of the diseases. However, incidences of anestrus, dystocia and RB, abortion, cervico-vaginal prolapse and RFM were found highest in age group of $\leq 3$ and $4-7$ and $\geq 8$ years, respectively. Parity had significant effect on incidences of anestrus $(\mathrm{P}<0.05)$ and $\mathrm{RB}(\mathrm{P}<0.01)$ however, had no significance effect on other disorders. The result specified adverse climatic condition, low $\mathrm{pH}$ of soil, poor managemental practices by dairy producers had contributed in the occurrence of reproductive disorders. Therefore, knowledge regarding the prevalence and factor associated with reproductive diseases could be fruitful to alleviate the problem.
\end{abstract}

\section{HIGHLIGHTS}

0 Incidence of reproductive disorder in crossbred cows was 32.13 per cent.

(0 The anestrus and repeat breeding were most common reproductive disorder in Assam region.

(0 The age and parity were the predisposing factors of infertility

Keywords: Cow, incidence, age, parity, anestrus, repeat breeding

The livestock sector is an important component of agriculture in the Indian economy. The sector has been an important source of livelihood for small and marginal farmers. India is the world's highest livestock owner with 192.49 million cattle. Even with the huge population of cattle and their economic significance, the productivity is low due to the poor reproductive performance. The productivity of a farm depends on the management of herd fertility and act as an important component of a profitable farm whereas reproductive inefficiency in dairy cows can affect the economy of the dairy industry. Reproductive problems cause significant economic loss to the dairy industry due to prolonged inter-calving period, slower uterine involution, lower reproductive rate, drop in milk production, diminished calf crop, early depreciation of high yielding cows (Kumar et al., 2014). Cows with reproductive problems is a challenge for both veterinarians and dairy producers. It has been reported that reproductive disorders could result in loss of INR $1,63,800$ in 180 days (Rawat et al., 2014) which could impact heavily to dairy producer of farmer. Therefore, it is reasonable to

How to cite this article: Dixit, C.P., Bhuyan, D., Bhuyan, M., Ahmed, K. Haloi, S., Borpujari, D., Chakravarty, H., Ikpe, A.B. and Lyngdoh, M.N (2020). Prevalence of various reproductive disorders in the foothills of Himalaya. J. Anim. Res., 10(4): 635-640.

Source of Support: None; Conflict of Interest: None (क) 9 
generate scientific information and database to determine the incidence of the various reproductive disorder in dairy cows. It is expected that the generated information could be used as a basis for prevention and interventions against reproductive disorder with an objective to improve dairy productivity.

\section{MATERIALS AND METHODS}

\section{Area and period of study}

Assam, the North-Eastern state lies between $26^{\circ} 19^{\prime} 00^{\prime \prime}$ $\mathrm{N}-27^{\circ} 59 ; 00^{\prime \prime} \mathrm{N}$ latitude to $89^{\circ} 57^{\prime} 00^{\prime \prime} \mathrm{E}-96^{\circ} 00^{\prime} 00^{\prime}$ " E longitude. Heavy rainfall (1500 $\mathrm{mm}$ to $2600 \mathrm{~mm}$ ) and hot humid climate are the characteristics weather of the study area. The study was conducted in and around Guwahati city of Assam during the period of one year from May 2018 to June 2019 to investigate the incidence of various reproductive disorders. All the animals reared under the intensive system, with alike pattern of feeding and housing were selected.

\section{Data collection}

A total of 554 crossbred cows were screened to study the incidence of various reproductive disorders based on history and clinico-gynaecological examination. The incidence of reproductive health disorders was determined as a proportion of affected animal out of the total animal surveyed. The organized questionnaire was drawn up and used to gather information from dairy owners. The objective of the study and its importance and how it will help their dairy farms were briefed to the owners using local language (Assamese). The information includes the age, parity, feeding system, date of last artificial insemination (AI), date of last calving, type of feed and history of reproductive disorders such as anestrus, repeat breeding (RB), retained fetal membrane (RFM), abortion, dystocia and cervico-vaginal prolapse were collected on individual cattle basis.

\section{Data management and analysis}

The data obtained from the questionnaire and regular follow up were entered and percentage of various reproductive disorder was derived using a Microsoft Excel version 10. The prevalence of reproductive problems was determined as the proportion of affected animals out of the total animal examined. The differences or association between different risk factors such as age and parity among all incidence of reproductive problems was analyzed by $\chi 2$ (Chi-square) technique using SPSS version 16. The value of $p<0.05$ considered as significant.

\section{RESULTS AND DISCUSSION}

The incidences of various reproductive disorders in crossbred cattle are presented in Table 1. In the present study, out of 554 crossbred cows surveyed, 178 (32.13\%) cow had reproductive disorders. The results were found well comparable with earlier reports of Acharya (2016) and Khan et al. (2016), who recorded the incidence of reproductive disorders as 33.85 and 30.23 per cent, respectively. In contrast, higher incidence of reproductive disorder was reported by Benti and Zewdie (2014; 47.7\%), Haile et al. (2014; 43.07\%) and Moges (2015; 49.29\%). While, Dutta (2017) recorded lower (14.63\%) population of crossbred cows affected with reproductive disorder under field conditions of Assam. The variation in the incidences of various reproductive disorders might be due to genotype of the animal, feeding practices, housing and breeding conditions, body condition score, environment stress, age, breed, parity, plane of nutrition, area of study, hormonal imbalance and management practices (Short et al., 1990; Heath et al., 1997; Baruselli et al., 2001; Quintans et al., 2009; Khan et al., 2016). The state receives heavy rainfall which might be responsible for the leaching of the nutrients from soil. The fodder grown in such soil is deficient in certain minerals and could not fulfill the nutrient requirement of the livestock. This might act as predisposing factor in occurrence of reproductive disorder in region of Assam.

The incidence of anestrus (51.12\%) recorded in the present study is in close agreement with Sorur et al. (1982) who recorded $49.9 \%$ incidence of anestrus. The findings were higher than the report of Khan et al. (2016; $31.79 \%$ ) while lower than the observation of Kutty and Ramachandaran $(2001 ; 65 \%)$ in crossbred cattle. The prominent explanation for higher incidence of anestrus in crossbred cattle is might be due to provision of low quality ration to the animals in the study area. It is well established that ultimate body condition score (BCS) 
extremely low or high at different stages of gestation leads to delay in onset of cyclicity (Butler and Smith, 1989; Pryce et al., 2000). Baruah et al. (2013) reported that the acidic $\mathrm{pH}$ of the soil during rainy season replaces basic cations $\left(\mathrm{Ca}^{2+}, \mathrm{Mg}^{2+}, \mathrm{Na}^{+}\right.$and $\left.\mathrm{K}^{+}\right)$leading to deprivation of minerals. Further, it is well known that nutrients play an important role in resumption of follicular growth (Smith and Akinbamijo, 2000), steroidogenesis and oxidative mechanism. Low energy availability decreases the LH pulse frequency which is critical to ovarian follicular development (Ibtisham et al., 2018). Higher incidence of parasitic infestation in the study area as well as inadequate scientific knowledge and poor managemental practices may be the reason for anestrus (Barkawi, 1984; Heath et al., 1997; Baruselli et al., 2001).

The RB was observed to be second prevalent disorder in the study with incidence of $33.71 \%$. Singh and Singh (2015) recorded the incidence as $37.44 \%$ which was in conformity with the present investigation. While the incidence recorded by Khan et al.(2016) was found lower $(24.61 \%)$ than the present observation. The predominant reason for repeat breeding was hormonal imbalance leading to anovulation, delayed ovulation as well cystic ovarian degeneration, early embryonic mortality. Further, low plane of nutrition and limited adaptability to the climatic condition by the crossbred cows in and around Guwahati city. Studies have also confirmed that nutrition can alter the follicular environment which affect oocyte maturation and development competence (Callaghan and Boland, 1999) or can cause early embryonic mortality. Furthermore, error in oestrus detection and lack of experienced inseminator are also responsible for repeat breeding (Noakes et al., 2009; Jainuddin and Hafez, 1993; Kumaresan, 2001).

The incidence of RFM in the study was recorded as $5.06 \%$ which was well accord with the findings of Haile et al. (2014, 7.18\%). It is well known that dystocia is the main predisposing factor for RFM (Gashaw et al., 2011) which is supported by the incidence rate of RFM corresponding to incidence of dystocia (4.50\%) in the present study. The present finding for dystocia is well comparable with report of Khan et al. $(2016 ; 5.12 \%)$ but was lower $(7.75 \%)$ and higher $(3.8 \%)$ than the observations of Dawit and Ahmed (2013) and Gashaw et al. (2011), respectively.

The incidence of abortion (2.81\%) reported in the present study is similar to the report of Haile et al. $(2014 ; 2.56 \%)$ but found lower $(11.25 \%)$ than the observation of Khan et al. (2016). The lower incidence of abortion might be due to growing practice of $\mathrm{AI}$ in the study area where semen is obtained from the disease free bulls under sanitation practices (Robert, 1986; Noakes et al., 2009; Gashaw et al., 2011).

In the present report, incidence of cervico-vaginal prolapse $(2.81 \%)$ was fairly consistent with the findings of Haile et al. $(2014 ; 3.44 \%)$. The observation was higher than reports of Hadush et al. (2013; 1.95\%), Khan et al. (2016; 1.53\%) and lower than the Kidhusan $(2009 ; 5.2 \%)$. The variation in the incidence of cervico-vaginal prolapse might be due to sample size and managemental practices (Noakes et al., 2009; Haile et al., 2014).

Table 1: Incidence of various reproductive disorders in crossbred cows $(\mathrm{n}=178)$

\begin{tabular}{lll}
\hline Reproductive disorders & $\begin{array}{l}\text { Number of } \\
\text { affected animals }\end{array}$ & Incidence (\%) \\
\hline Anestrus & 91 & 51.12 \\
Repeat breeding & 60 & 33.71 \\
Abortion & 5 & 2.81 \\
Retention of fetal membrane & 9 & 5.06 \\
Dystocia & 8 & 4.50 \\
Cervico-vaginal prolapse & 5 & 2.81 \\
\hline Total & $\mathbf{1 7 8}$ & $\mathbf{1 0 0}$ \\
\hline
\end{tabular}

$\mathrm{n}=$ total animal affected; Age-wise incidence of various reproductive disorders.

The age wise incidence of various reproductive disorders in crossbred cows has been shown in Table 2. In the present study, non-significant $(p>0.05)$ difference was observed among various reproductive disorders between different age groups. In the present investigation, highest incidence of anestrus and dystocia was observed in the age group of $\leq 3$ years. The incidence of RB and abortion, cervicovaginal prolapse were observed in age group of 4-5 and 6-7 years, respectively. The cows in age group of $\geq 8$ years showed highest incidence of RFM in this study.

Short et al. (1990) reported that the cows in first lactation require more time to resume ovarian activity than pluriparous cows. Such animals have higher energy priority for growth and lactation rather than reproduction resulting in state of postpartum anestrus. The poor body 
Table 2: Effect of age on the incidence of various reproductive disorders in crossbred cows

\begin{tabular}{|c|c|c|c|c|c|c|c|c|c|}
\hline \multirow{3}{*}{$\begin{array}{l}\text { Reproductive } \\
\text { Disorders }\end{array}$} & \multicolumn{8}{|c|}{ Age groups } & \multirow{3}{*}{$\begin{array}{l}\text { - Value of }{ }_{\chi}^{2} \\
\text { - between age } \\
\text { groups }\end{array}$} \\
\hline & \multicolumn{2}{|c|}{$\leq 3 \operatorname{yrs}(n=33)$} & \multicolumn{2}{|c|}{$4-5$ yrs $(n=46)$} & \multicolumn{2}{|c|}{$6-7$ yrs $(n=64)$} & \multicolumn{2}{|c|}{$\geq 8$ yrs $(n=35)$} & \\
\hline & $\begin{array}{l}\text { No. of } \\
\text { observation }\end{array}$ & $\begin{array}{l}\text { Incidence } \\
(\%)\end{array}$ & $\begin{array}{l}\text { No. of } \\
\text { observation }\end{array}$ & $\begin{array}{l}\text { Incidence } \\
(\%)\end{array}$ & $\begin{array}{l}\text { No. of } \\
\text { observation }\end{array}$ & $\begin{array}{l}\text { Incidence } \\
(\%)\end{array}$ & $\begin{array}{l}\text { No. of } \\
\text { observation }\end{array}$ & $\begin{array}{l}\text { Incidence } \\
(\%)\end{array}$ & \\
\hline Anestrus & 21 & 63.64 & 21 & 45.65 & 32 & 50.00 & 17 & 48.57 & $2.72^{\mathrm{NS}}$ \\
\hline Repeat breeding & 6 & 18.18 & 20 & 43.48 & 22 & 34.38 & 12 & 34.29 & $5.50^{\mathrm{NS}}$ \\
\hline Abortion & 1 & 3.03 & 1 & 2.17 & 2 & 3.13 & 1 & 2.86 & $0.09^{\mathrm{NS}}$ \\
\hline $\begin{array}{l}\text { Retention of fetal } \\
\text { membrane }\end{array}$ & 1 & 3.03 & 1 & 2.17 & 4 & 6.25 & 3 & 8.57 & $2.17^{\mathrm{NS}}$ \\
\hline Dystocia & 4 & 12.12 & 2 & 4.35 & 1 & 1.56 & 1 & 2.86 & $5.30^{\mathrm{NS}}$ \\
\hline $\begin{array}{l}\text { Cervico-vaginal } \\
\text { prolapse }\end{array}$ & 0 & 0.00 & 1 & 2.17 & 3 & 4.69 & 1 & 2.86 & $1.86^{\mathrm{NS}}$ \\
\hline
\end{tabular}

$\mathrm{n}$ indicates number of animals in different age groups; NS indicates non significant.

Table 3: Effect of parity on the incidence of various reproductive disorders in crossbred cows

\begin{tabular}{|c|c|c|c|c|c|c|c|}
\hline \multirow[b]{2}{*}{$\begin{array}{l}\text { Reproductive } \\
\text { Disorders }\end{array}$} & \multicolumn{2}{|c|}{$1^{\text {st }}$ Parity $(n=57)$} & \multicolumn{2}{|c|}{$2^{\text {nd }}$ Parity $(n=46)$} & \multicolumn{2}{|c|}{$\geq 3^{\text {rd }}$ Parity $(n=75)$} & \multirow[b]{2}{*}{$\begin{array}{l}\text { Value of } \chi^{2} \text { between } \\
\text { parity groups }\end{array}$} \\
\hline & $\begin{array}{l}\text { No. of } \\
\text { observation }\end{array}$ & $\begin{array}{l}\text { Incidence } \\
(\%)\end{array}$ & $\begin{array}{l}\text { No. of } \\
\text { observation }\end{array}$ & $\begin{array}{l}\text { Incidence } \\
(\%)\end{array}$ & $\begin{array}{l}\text { No. of } \\
\text { observation }\end{array}$ & $\begin{array}{l}\text { Incidence } \\
(\%)\end{array}$ & \\
\hline Anestrus & 38 & 66.67 & 18 & 39.13 & 35 & 46.67 & $8.77^{*}$ \\
\hline Repeat breeding & 11 & 19.30 & 22 & 47.83 & 27 & 36.00 & $9.57 * *$ \\
\hline Abortion & 1 & 1.75 & 2 & 4.35 & 2 & 2.67 & $0.63^{\mathrm{NS}}$ \\
\hline Retention of fetal membrane & 2 & 3.51 & 2 & 4.35 & 5 & 6.67 & $0.73^{\mathrm{NS}}$ \\
\hline Dystocia & 5 & 8.77 & 1 & 2.17 & 2 & 2.67 & $3.59^{\mathrm{NS}}$ \\
\hline Cervico-vaginal prolapse & 0 & 0.00 & 1 & 2.17 & 4 & 5.33 & $3.46^{\mathrm{NS}}$ \\
\hline
\end{tabular}

$\mathrm{n}$ indicates number of animals in different parity groups; $* \mathrm{P}<0.05, * * \mathrm{P}<0.01$; NS indicates non significant.

condition score due to unavailability of good quality fodder in the area of Assam may result in poor pelvic growth and development leading to dystocia. The mineral deficit soil of the study area may employ the occurrence of RB, abortion and cervico-vaginal prolapse. Further, the hot and humid climate negatively affect the oocyte, corpum luteum, embryo quality and steroidogenesis resulting in conception failure and embryonic mortality (Wolfenson and Roth, 2019). This ultimately leads to RB and abortion as a resultant of heat stress. However, the effect of mineral deficiency and heat stress on age group of 4 to 7 years in the study remain unknown. The higher observation of RFM with advancement of age in this report might be due to poor tonicity of uterus leading to inability to expel the fetal membrane.

\section{Parity-wise incidence of various reproductive disorders}

The parity-wise incidence of animals affected with various reproductive disorders are presented in Table 3. Test of significance $\left(\chi^{2}\right)$ indicated significant difference in the incidence of anestrus $(p<0.05)$ and $\mathrm{RB}(p<0.01)$ between different parity groups. However, Chi square test indicated non-significant difference $(p>0.05)$ in the prevalence of abortion, RFM, dystocia and cervico-vaginal prolapse between parities. The incidences of anestrus and dystocia were observed to be highest in $1^{\text {st }}$ parity. The prevalence of $\mathrm{RB}$ and abortion were found greatest in $2^{\text {nd }}$ parity. While, highest incidence of RFM and cervico-vaginal prolapse were observed in $3^{\text {rd }}$ parity group. The higher incidences of anestrus, RB and dystocia were observed in animals with $\leq 3$ parity by Khan et al. (2016) and Bhat et al. (2012).

Greater difficulty has been reported in resumption of postpartum ovarian cyclicity in primiparous by Ahmadzadeh, et al. (2011). The authors stated that the heavy energy requirement for growth and lactation negatively affect reproduction in first-calver cows. It is 
the widely known that feto-maternal disproportion is the leading cause of dystocia in primiparous animals (Noakes $e t$ al., 2018). This might be responsible for higher prevalence of dystocia in $1^{\text {st }}$ parity in the present study. Furthermore, artificial breeding using semen from the large size bull without taking into account the size and age of recipient cows is the precipitating cause of dystocia (Haile et al., 2014). Similar to the present finding, increased services per conception in 2 parity has been reported by Yusuf et al. (2017). The authors stated that greater risk of embryonic mortality with increase in parity consequently increases the prevalence of RB (Yusuf et al., 2010). The high yielder cows has increase hepatic blood flow which might be responsible for rapid steroid metabolism (Vasconcelos et al., 2003). As progesterone is requisite for maintenance of pregnancy, low level of progesterone during lactation stress compromises embryo survival leading to abortion (Jousan et al., 2005). The hypocalcemia with increase in lactation yield during $\geq 3^{\text {rd }}$ parity serve as predisposing factor in occurrence of RFM and cervico-vaginal prolapse. The lower plasma calcium concentration in cows affected with RFM (Melendez et al., 2004) and cervico-vaginal proplase (Honnappagol and Tandle, 2010) has been reported which might be responsible for poor uterine atony leading to failure of expulsion of placental membrane and genital prolapse.

\section{CONCLUSION}

The study investigated incidence of various reproductive disorders in the North-Eastern region of India. The study revealed anestrus followed by RB, RFM, dystocia, abortion and cervico-vaginal prolapse as the major reproductive problems in the region of Assam. The age and parity of an animal were found to be the risk factors in the occurrence of reproductive diseases. The hot and humid climate, mineral deficit soil of the area and lack of breeding knowledge were observed to be the bigger constraint faced by the farmers against the fertility improvement. The knowledge about the incidences could be beneficial to the farmers and dairy producers for the improvement and management of reproductive diseases. The implementation of preventive measures could be helpful in enhancement of fertility. Emphasis on proper nutrition and management is highly imperative in order to maximize the productivity of dairy cows.

\section{ACKNOWLEDGEMENTS}

The authors are thankful to the Dr. Motiur Rahman, manager Government of livestock farm, Khanapara, Assam for his support throughout the study. Thanks are also extended to dairy producers from region around Guwahati city for their co-operation during survey.

\section{REFERENCES}

Acharya, C. 2016. A study of reproductive disorders in crossbred cattle with special reference to repeat breeding. M.V.Sc. Thesis, Assam Agricultural University, Guwahati, Assam, India.

Ahmadzadeh, A., Carnahan, K. and Autran, C. 2011. Understanding puberty and postpartum anestrus. In: Proceedings of applied reproductive strategies in beef cattle. 31: 45-60.

Barkawi, A.H. 1984. Prepartum and postpartum hormonal pattern and reproductive activity in Egyptian buffaloes. Ph.D. Thesis. Cairo University.

Baruah, B.K., Das, B., Medhi, C. and Misra, A.K. 2013. Fertility status of soil in the tea garden belts of Golaghat district, Assam, India. J. Chem., Article ID 983297.

Baruselli, P.S., Barnabe, V.H., Barnabe, R.C., Visintin, J.A., Molero-Filho, J.R. and Porto, R. 2001. Effect of body condition score at calving on postpartum reproductive performance in buffalo. Buffalo J., 17: 53-66.

Benti, A.D. and Zewdie, W. 2014. Major reproductive health problems of indigenous Borena cows in Ethiopia. J. Adv. Vet. Anim. Res., 1: 182-188.

Bhat, F.A., Bhattacharyya, H.K. and Khan, M.Z. 2012. Studies on prevalence of repeat breeding in crossbred cattle of Kashmir valley. Indian J. Anim. Res., 46: 306-309.

Butler, W.R. and Smith, R.D. 1989. Interrelationships between energy balance and postpartum reproductive function in dairy cattle. J. Dairy Sci.,72: 767-783.

Dawit, T. and Ahmed, S. 2013. Reproductive health problems of cows under different management systems in Kombolcha, Northeast Ethiopia. Hawassa University, School of Veterinary Medicine, Hawassa, Ethiopia. Adv. Biol. Res., 7: 104-108.

Dutta, L.J. 2017. Upscaling of bovine infertility countering technologies, Ph.D. Thesis, Assam Agricultural University, Guwahati, Assam, India.

Gashaw, A., Worku, F. and Mulugeta, S. 2011. Assessment of small holder dairy production system and their reproductive health problems in Jimma town, Southwestern Ethiopia. Int. J. Appl. Res. Vet. Med., 9: 80-86. 
Hadush, A., Abdella, A. and Regassa, F. 2013. Major prepartum and postpartum reproductive problems of dairy cattle in Central Ethiopia. J. Vet. Med. Anim. Health, 5: 118-123.

Haile, A., Tsegaye, Y. and Tesfaye, N. 2014. Assessment of major reproductive disorders of dairy cattle in urban and per urban area of Hosanna, Southern Ethiopia. Environment, 8: 22.

Heath, H.L., Blagburn, B.L., Elsasser, T.H., Pugh, D.G., Sanders, L.G., Sartin, E.A., Steele, B. and Sartin, J.L. 1997. Hormonal modulation of the physiologic responses of calves infected with Eimeria bovis. Am. J. Vet. Res., 58: 891-896.

Honnappagol, S. and Tandle, M.K. 2010. Artificial Insemination and Treatment of Infertility in Dairy Animals, New India Publishing, India.

Ibtisham, F., Nawab, A.A.M.I.R., Li, G., Xiao, M., An, L. and Naseer, G. 2018. Effect of nutrition on reproductive efficiency of dairy animals. Med. Weter., 74: 356-361.

Jainuddin, M.R. and Hafez, E.S.E. 1993. Reproduction in Farm Animals, Lea and Febiger. Philadelphia.

Jousan, F.D., Drost, M. and Hansen, P.J. 2005. Factors associated with early and mid-to-late fetal loss in lactating and nonlactating Holstein cattle in a hot climate. J. Anim. Sci., 83: 1017-1022.

Khan, M.H., Manoj, K. and Pramod, S. 2016. Reproductive disorders in dairy cattle under semi-intensive system of rearing in North-Eastern India. Vet. World, 9: 512.

Kidusan, K. 2009. Study on major reproductive disorders of dairy cattle in and around Wukro. DVM Thesis, College of Veterinary Medicine, Mekelle University, Tigray, Northern Ethiopia, unpublished.

Kumar, P.R., Singh, S.K., Kharche, S.D., Govindaraju, C.S., Behera, B.K., Shukla, S.N., Kumar, H. and Agarwal, S.K. 2014. Anestrus in cattle and buffalo: Indian perspective. $A d v$. Anim. Vet Sci., 2: 124-138.

Kumaresan, A. 2001. Repeat breeding syndrome in cattle and buffaloes; therapeutic approach at field level. Pashudhan, 16: 4.

Kutty, C.I. and Ramachandran, K. 2001. Bovine infertility - A field oriented categorization based on investigation among crossbred cattle in a district of Kerala. Indian J. Anim. Sci., 73: $155-157$.

Melendez, P., Donovan, G.A., Risco, C.A. and Goff, J.P. 2004. Plasma mineral and energy metabolite concentrations in dairy cows fed an anionic prepartum diet that did or did not have retained fetal membranes after parturition. Am. J. Vet. Res., 65: 1071-1076.

Moges, N. 2015. Survey on dairy farm management and infertility problems in small, medium and large scale dairy farms in and around Gondar, North West Ethiopia. J. Dairy Vet. Anim. Res., 2: 202-207.

Noakes, D.E., Parkinson, T.J. and England, G.C.W. 2009. Veterinary Reproduction and Obstetrics, WB Saunders Company, London.

Noakes, D.E., Parkinson, T.J. and England, G.C.W. 2018. Veterinary Reproduction and Obstetrics, WB Saunders Company, London.

Pryce, J.E., Coffey, M.P. and Brotherstone, S. 2000. The genetic relationship between calving interval, body condition score and linear type and management traits in registered Holsteins. J. Dairy Sci., 83: 2664-2671.

Quintans, G., Vázquez, A.I. and Weigel, K.A. 2009. Effect of suckling restriction with nose plates and premature weaning on postpartum anestrous interval in primiparous cows under range conditions. Anim. Reprod. Sci., 116: 10-18.

Rawat, K.D., Chaudhary, S., Kumar, N., Gupta, S., Chaubey, K.K., Singh, S.V., Dhama, K. and Deb, R. 2014. Economic losses in a commercial dairy farm due to the outbreak of Johne's disease in India. Res. J. Vet.Prac., 2: 73-77.

Robert, S.J. 1986. Veterinary Obstetrics and Genital Diseases, Edwards' Brothers. Inc. Michigan.

Short, R.E., Bellows, R.A., Staigmiller, R.B., Berardinelli, J.G. and Custer, E.E. 1990. Physiological mechanisms controlling anestrus and infertility in postpartum beef cattle. J. Anim. Sci., 68: 799-816.

Singh, N.J. and Singh, A. 2015. The gynecological disorders in dairy cattle on the survey of Allahabad. Int. J. Sci. Res., 4: 597-599.

Smith, O.B. and Akinbamijo, O.O. 2000. Micronutrients and reproduction in farm animals. Anim. Reprod. Sci., 60: 549560.

Sorur, B.H., Farrag, A.A. and Gomaa, A. 1982. Incidence of certain infertility problems among cows and buffaloes in Upper Egypt. Assiut Vet. Med. J., 10: 209-214.

Vasconcelos, J.L.M., Sangsritavong, S., Tsai, S.J. and Wiltbank, M.C. 2003. Acute reduction in serum progesterone concentrations after feed intake in dairy cows. Theriogenology, 60: 795-807.

Wolfenson, D. and Roth, Z. 2019. Impact of heat stress on cow reproduction and fertility. Anim. Front, 9: 32-38.

Yusuf, M., Nakao, T., Long, S.T. and Gautam, G. 2010. Analysis of some factors affecting fertility levels in a high-producing dairy herd in south-western Japan. Anim. Sci. J., 81: 467-474.

Yusuf, M., Toleng, A.L., Rahardja, D.P., Ako, A., Sahiruddin. And Eriansyah, A. 2017. Reproductive performance of dairy cows at different parities (A case study in Enrekang Regency, Indonesia). J. Adv. Agric. Technol., 4: 331-334. 